\title{
WATER CONSERVATION IN THE NURSERY SCHOOL
}

\section{SAMALTANI,* \\ V. CHRISTIDOU}

Received: $25 / 02 / 10$

Accepted: 23/12/10
Department of Preschool Education University of Thessaly Volos, 38221, Greece

${ }^{1, *}$ to whom all correspondence should be addressed: e-mail: vchristi@ece.uth.gr

\begin{abstract}
Water shortage is an environmental problem that requires changes in terms of thinking and everyday practice. Education for a sustainable development should therefore aim at arousing pupils' awareness on this issue and inducing rational use of water in future citizens. The present study explores the effectiveness of a program designed for preschool children in promoting their awareness of water shortage and the importance of water conservation. A class of seventeen 5-6 year-old children participated in the study. Initially the relevant pre-existing views of the participants were recorded (pre-test). Subsequently, the program was implemented. It consisted of twelve interdisciplinary activities aiming at enhancing children's awareness of water conservation both at the level of understanding and at the level of values and attitudes. Finally, the development of children's awareness was tested (post-test). The results of the study indicate that preschool children are capable of tackling with the value of water for life, the issue of its shortage and the importance of its conservation at a primary level. Water conservation is therefore a topic that can introduce young children to the concepts of man-environment interaction and interdependence, and to assist them in developing the ability to participate in finding solutions to environmental problems.
\end{abstract}

KEYWORDS: Education for a sustainable development, interdisciplinarity, preschool children, water shortage, water conservation.

\section{INTRODUCTION}

"We can't demand nature to provide us with fresh water on one hand and swallow and assimilate our waste on the other" (Bougouerra, 2000). Water is a natural resource, indispensable for life and abundant on earth. However, the available amount of consumable water does not exceed $1 \%$ of the total amount of water on the planet (Chiras, 1985; European Communities, 2001) and, more importantly, is not uniformly distributed on it.

Since global water needs are rapidly increasing, while the available water remains constant in quantity (and degrades in quality), its conservation has become of primary concern (Chiras, 1985; Global Water Partnership, 2000). According to Chapter 18 of Agenda 21 a general objective is to make certain that adequate supplies of water of good quality are maintained for the entire population of this planet, treating freshwater as a finite and vulnerable resource. For this reason effective implementation and coordination mechanisms are required. All states should therefore design and instigate targeted action programmes, and put in place appropriate institutional structures in order to establish efficient water-use programmes to attain sustainable resource utilization patterns (UNEP, 2000).

Environmental issues involve complex processes and interdependences that require a comprehensive synthesis of information from different disciplines in order to understand them; they have a strong social dimension, they are associated with everyday practice and with the future of the planet and consequently they affect all pupils, a fact which suggests the need for a holistic and interdisciplinary approach (Brody, 1991; 1994).

Water shortage and conservation constitute major environmental issues, which require changes at the level of thinking and everyday behaviour. Thus, understanding water shortage and conservation and developing appropriate attitudes and values are suggested as primary and topical issues for negotiation at school (UNESCO, 1994; Middlestadt et al., 2001). This subject in particular, is 
appropriate for inclusion in preschool education programs, since young children have relevant practical experience, and thus they can access its conceptual complexity at a preliminary level.

From their early years, children develop their knowledge, values and ways of reasoning in relation to the world they live in. This development is influenced by different factors, the most important of which are direct sensory experience and the participation in everyday social life and in formal education (Matthews, 1994; Fleer \& Robbins, 2003; Tytler \& Peterson, 2001). Education, from the early years, has a fundamental role to play in providing children with problem recognition and solving skills and encouraging behaviours that are compatible with environmental quality preservation (Sheehy et al., 2000) as well as sustainable use of natural resources, such as water.

A central objective of preschool education is to support the holistic development of children. Obviously, approaching the environment through relevant teaching activities has its own place in such a general purpose. Therefore, education from the early years can promote the formation of a society able and willing to ensure a 'sustainable' future, since the better one can understand an environmental problem, the most positive attitudes and the most effective behaviour (s)he can be expected to adopt (Bybee, 1993; Volk, 1984). Through dealing with important and current environmental issues, the pupils face real situations and realize that making critical decisions, presupposes gathering and processing (scientific) information (Brody, 1991; 1994; Brody et al., 1989).

The consequences of human activities on the planet seem to increasingly concern citizens. Children are informed about critical environmental issues through different sources apart from school (e.g. through the media) and it is estimated that -despite the basic difficulties in understanding their complexity- they shape their own and simplified conceptions of important scientific and environmental issues even before their participation in relevant educational programs (Christidou \& Koulaidis, 1996; Dimitriou \& Christidou, 2007; Koulaidis \& Christidou, 1999; Palmer, 1994; Solomon, 1993).

Additionally, it is suggested that children's experiences related to the natural environment influence the development of a personal interest about it. This implies the need for appropriately designed instructional programs and material aiming at contributing to the development of knowledge and attitudes compatible with a future "ecological" behaviour (Palmer \& Suggate, 1996). The use of appropriate instructional strategies can help pupils untangle complex phenomena, which are related to important environmental issues (Marinopoulos \& Stavridou, 2002), and express a positive concern about the environment (Bonnett \& Jacquetta , 1998).

The study presented in this paper involves teaching water conservation to preschool children. Specifically, the design, implementation, and evaluation of an instructional program about this issue will be outlined. The aim of the program was to facilitate children's understanding of the problem of water shortage and improve their attitudes towards water conservation. Therefore, this study focuses on exploring and enhancing a) the importance that children attribute to water for life; b) their level of knowledge about the uneven distribution of water on the planet; c) their perceptions of the uses of water in daily activities and the possibility of water shortage; d) their understanding of the importance and ways of saving water and their intentions for personal involvement; and e) their suggestions for actions aiming at informing the community about the issue.

\section{METHOD}

\section{Sample and procedure}

Seventeen preschool children (13 girls and 4 boys) participated in the study. Their ages ranged between 5-6 years, and they were attending a public nursery school in the city of Volos, Greece, for at least 2 years.

Personal, semi-structured interviews were conducted prior to (pre-test) and after (post-test) the realization of an instructional program ("Saving water", see description below). The interviews aimed at investigating what children already knew about water and their attitudes towards its sustainable use. A week after the pre-test interviews had completed, the program "Saving water" was implemented. Fifteen days after the conclusion of the program, personal interviews were conducted again (post-test) with the children.

Pre- and post-test interviews were conducted using an interview scheme which was structured for this purpose. The interview scheme consisted of 18 questions (see Appendix 1). The technique of personal, semi-structured interviews was selected since it allows in-depth investigation of children's 
views, giving insight to their conceptualizations of phenomena of the natural world and revealing critical aspects of their way of thinking (Cohen \& Manion, 1994; Powney \& Watts, 1987).

The questions posed to the children related to the sources of water, its value for life, its uses in everyday life, the possibility of water shortage, the solutions they suggest for its conservation, and the possible ways of informing their community about water shortage and conservation.

\section{"Saving water": description of the program}

The "Saving water" program consisted of 12 activities that took place three times a week over a period of one month. The program combined cognitive and affective objectives attuned to the general principles of Environmental Education (Flogaiti, 1998).

At the cognitive level the program focused on the concepts of water uneven distribution on the planet, its necessity for life, the use of water in everyday life and the appropriate actions and measures to save it, the degradation of water resources, and the consequences of wasting water.

The program also sought to inspire values related to the children's interest and concern for the improvement of life conditions for all people and to the consequences of human activities on the quality of life and the environment. It therefore concentrated on the contemporary way of living leading to unsustainable water use, the consequences of related actions, the possible alternatives for saving water, and the appropriate actions for informing the public.

At the level of attitudes the program aimed at raising children's interest and willingness to take actions related to water conservation, as well as encouraging their readiness to actively participate in resolving the problem of water waste and shortage.

The approach adopted addressed the issue of water conservation in a holistic manner, indicating that human beings are part of a complex and sensitive system of interrelated components (i.e. other living things, soil, water, etc.) sustaining life.

At the same time the program set goals derived from the current interdisciplinary Greek curriculum for preschool education (Ministry of National Education and Religious Affairs, 2002). In particular, the program goals encompassed objectives from the following fields:

- Geography, including "reading" simple maps and recognizing symbolic representations (e.g. of lakes and rivers).

- Biology, including a) broadening children's knowledge about the environment, and b) recognizing the importance of water for life and survival.

- Mathematics, including producing visual representations of relations on reference tables.

- Language (oral communication), including a) performing speech acts such as describing, explaining, formulating questions and arguing, and b) using specialized vocabulary about water shortage and conservation.

- Literacy, including a) understanding a narration, b) locating and discerning basic written expressions, and c) 'decoding' simple legends or captions.

- Art, including a) using a variety of materials in order to draw, b) recognizing colors in the environment and understanding their symbolic representation on paper, and c) selecting available material (images, photographs, graphs, written text, their own drawings) in order to construct a poster.

- Drama, including self-expression trough role play.

The structure of the program is described in Table 1 below. 
Table 1. Structure and description of the "Saving water" program

\begin{tabular}{|c|c|c|c|}
\hline \multicolumn{2}{|r|}{ Activity } & Objectives & \multirow{2}{*}{$\begin{array}{l}\text { Description } \\
\text { A water bill from the local water supply company was used in order to initiate a } \\
\text { discussion of water and its everyday use. }\end{array}$} \\
\hline 1 & $\begin{array}{l}\text { Introduction of the topic of } \\
\text { water use }\end{array}$ & $\begin{array}{l}\text { Activate children's existing knowledge } \\
\text { and interest about water }\end{array}$ & \\
\hline 2 & $\begin{array}{l}\text { A visit to the local water } \\
\text { supply company }\end{array}$ & $\begin{array}{l}\text { Learn about the sources of water and its } \\
\text { route to our houses. }\end{array}$ & $\begin{array}{l}\text { The class visited the local water supply company. Afterwards a leaflet showing the } \\
\text { route of water was suspended in the class and the children were given a worksheet } \\
\text { and were asked to help water find its way. }\end{array}$ \\
\hline 3 & $\begin{array}{l}\text { Water distribution on our } \\
\text { planet }\end{array}$ & $\begin{array}{l}\text { Appreciate that water is not uniformly } \\
\text { distributed on earth, realize that the } \\
\text { quantity of available drinking water is } \\
\text { limited and affects everyday practices. }\end{array}$ & $\begin{array}{l}\text { Children worked in two groups. Each group was given two sets of photos which } \\
\text { depicted water abundance and shortage correspondingly. One of the groups was } \\
\text { asked to locate the photos illustrating water abundance, while the other located } \\
\text { those illustrating water shortage. Each group had to justify their judgment. }\end{array}$ \\
\hline 4 & The earth: a blue planet & $\begin{array}{l}\text { Realize that the largest part of the } \\
\text { planet's surface is covered with water, } \\
\text { most of which is not available for } \\
\text { domestic use. }\end{array}$ & $\begin{array}{l}\text { With the use of a satellite photo the children found out that the earth looks blue from } \\
\text { very far away. Later they detected the areas on the globe that indicate the presence } \\
\text { of water such as lakes, rivers and oceans, they discussed their observations and } \\
\text { concluded that the planet has plenty of water but most of it is not drinkable. }\end{array}$ \\
\hline 5 & Water shortage & $\begin{array}{l}\text { Familiarize the children with the uneven } \\
\text { water distribution on earth and the } \\
\text { resulting problem of water scarcity in } \\
\text { certain parts of the world. }\end{array}$ & $\begin{array}{l}\text { A representative of "One Earth" -an environmental NGO- was invited to the class } \\
\text { and talked to the children about the regions that suffer from water scarcity. }\end{array}$ \\
\hline 6 & $\begin{array}{l}\text { Can there be life without } \\
\text { water? }\end{array}$ & $\begin{array}{l}\text { Realize the value of water for life and the } \\
\text { interaction between human beings and } \\
\text { the environment. }\end{array}$ & $\begin{array}{l}\text { Two plants were planted and the one was watered while the other was not. The } \\
\text { children predicted what would happen to each plant and after a few days they } \\
\text { concluded that the plant that was not watered could not live. The outcomes of this } \\
\text { investigation were discussed in relation to water needs for farming and the } \\
\text { availability of freshwater in different regions. }\end{array}$ \\
\hline 7 & A fair share & $\begin{array}{l}\text { Introduce water conservation through } \\
\text { role play. }\end{array}$ & $\begin{array}{l}\text { A story about a giant who lives on the top of a mountain and wastes water, while the } \\
\text { people living nearby cannot water their land, have no water to drink and are about } \\
\text { to die was narrated to the children. They were encouraged to propose their own } \\
\text { ending for the story using drama and role-play. The children decided to elect a } \\
\text { committee of the affected citizens. The committee visited the giant and suggested } \\
\text { ways of saving water. }\end{array}$ \\
\hline 8 & Simulating water shortage & $\begin{array}{l}\text { Appreciate the value of water in everyday } \\
\text { practice and think about the } \\
\text { consequences of its shortage. }\end{array}$ & $\begin{array}{l}\text { The teacher switched off the school water supply for some hours. The class } \\
\text { discussed and realized that several daily activities require water, and that its } \\
\text { shortage creates problems. }\end{array}$ \\
\hline 9 & $\begin{array}{l}\text { Uses of water at home and } \\
\text { at school }\end{array}$ & $\begin{array}{l}\text { List different uses of water at school and } \\
\text { at home and find out the amount of water } \\
\text { used in different daily activities. }\end{array}$ & $\begin{array}{l}\text { A table with the uses of water at school was hanged on the classroom wall and the } \\
\text { uses of water were marked each day. A similar table with domestic water uses was } \\
\text { given to every child to record their daily uses of water at home for a week. Another } \\
\text { table was constructed by the class comparing the uses at school and at home and }\end{array}$ \\
\hline
\end{tabular}




\begin{tabular}{|l|l|l|l|}
\hline & & & $\begin{array}{l}\text { the children were encouraged to discuss and compare the types and amounts of } \\
\text { water use. }\end{array}$ \\
\hline 10 & Using water wisely & $\begin{array}{l}\text { Use a diversity of resources about water } \\
\text { conservation in order to encourage } \\
\text { relevant values and attitudes. }\end{array}$ & $\begin{array}{l}\text { Illustrated leaflets about water conservation were given to the children and with the } \\
\text { help of the teacher they 'decoded' the meanings of images and symbols to discern } \\
\text { sustainable behaviors relate to water use. }\end{array}$ \\
\hline 11 & Wasting and saving water & $\begin{array}{l}\text { Help children familiarize with practical } \\
\text { ways of saving water. }\end{array}$ & $\begin{array}{l}\text { The children, working in two groups were given pictures of different uses of water. } \\
\text { One group located sustainable water uses, while the other located the ones that } \\
\text { waste water. Each group presented their choices to the whole class and justified } \\
\text { their judgments. }\end{array}$ \\
\hline 12 & Making a poster & $\begin{array}{l}\text { Evaluate the children's ability to suggest } \\
\text { actions for sustainable water use and } \\
\text { their relevant attitudes. }\end{array}$ & $\begin{array}{l}\text { The class discussed ways of sending a message to the community and decided to } \\
\text { create informative posters. The children were divided in two groups and each group } \\
\text { made a poster to communicate the importance of saving water. }\end{array}$ \\
\hline
\end{tabular}




\section{RESULTS}

This section involves the evaluation of the 'Saving water' program by means of the comparison between the children's achievement in the pre- and post-test. Children's responses to the pre- and post-test questions were grouped in 5 themes concerning a) water sources and water processing and transfer to houses; b) the value of water for life and its distribution on the planet; c) everyday uses of water and the possibility of water shortage; d) ways of saving water; and e) suggestions to inform the community about the importance of saving water. Table 2 presents the average frequencies of responses provided by the children for each group of questions during the pre- and post-tests, as well as the relevant differences. These responses were categorized as 'adequate' when children exhibited a conceptual understanding of the topic under discussion, that is they gave appropriate answers and justifications, 'partly adequate', when acceptable answers were given but with no -or insufficient- justification, or 'inadequate', that is responses which revealed inappropriate conceptions. Moreover, in some cases the children were not able to give an answer to a particular question posed; these cases were coded as 'no answer'.

Table 2. Children's average responses to pre- and post- test question themes

\begin{tabular}{llccc}
\hline Theme & Response & Pre-test & Post-test & Difference \\
\hline Water sources and transfer & Adequate & 4 & 10.5 & +6.5 \\
\cline { 2 - 5 } (Questions 1 2) & Partly adequate & 7 & 5.5 & -1.5 \\
\cline { 2 - 5 } & Inadequate & 3.5 & 1 & -2.5 \\
\cline { 2 - 5 } & No answer & 2.5 & 0 & -2.5 \\
\hline Water value and distribution & Adequate & 8 & 15.4 & +7.4 \\
\cline { 2 - 5 } $\begin{array}{l}\text { on earth } \\
\text { (Questions 3-7) }\end{array}$ & Partly adequate & 5.8 & 1.4 & -4.4 \\
\cline { 2 - 5 } & Inadequate & 2.6 & 0 & -2.6 \\
\cline { 2 - 5 } & No answer & 0.6 & 0.2 & -0.4 \\
\hline Water uses and possibility of & Adequate & 7 & 12.8 & +5.8 \\
\cline { 2 - 5 } shortage & Partly adequate & 1.8 & 2.2 & +0.4 \\
\cline { 2 - 5 } (Questions 8-12) & Inadequate & 6.6 & 1.8 & -4.8 \\
\cline { 2 - 5 } & No answer & 1.6 & 0.2 & -1.4 \\
\hline Ways of saving water & Adequate & 5 & 12.8 & +7.8 \\
\cline { 2 - 5 } (Questions 13-17) & Partly adequate & 0.8 & 0.8 & 0 \\
\cline { 2 - 5 } & Inadequate & 7 & 2 & -5 \\
\cline { 2 - 5 } & No answer & 4.2 & 1.4 & -2.8 \\
\hline Suggestions to inform the & Adequate & 0 & 11 & +11 \\
\cline { 2 - 5 } $\begin{array}{l}\text { community } \\
\text { (Question 18) }\end{array}$ & Partly adequate & 5 & \multicolumn{1}{c}{3} & -4 \\
\cline { 2 - 5 } & Inadequate & 5 & 2 & -4 \\
\cline { 2 - 5 } & No answer & & &
\end{tabular}

Children's perceptions of water sources and water processing and transfer to houses (Questions 1 \& 2)

Children's knowledge about water sources and transfer developed significantly during the program, since their average adequate responses increased by 6.5. Initially, they tended to express partial and inadequate ideas about the sources, processing and route of water to our houses. During posttest they were able to give significantly more adequate responses, suggesting that "water comes to our houses from the lakes, the rivers, and the sources", or that "water comes to our houses from the drill, from rain, from the lakes and rivers", and "water goes to the pumps then to some factories and they clean it and then they bring it home".

\section{The value of water and its distribution on the planet (Questions 3 to 7 )}

During pre-test, the majority of children were not able to give appropriate answers concerning the importance of water for living things, or its uneven distribution on earth. For example, a 5-year-old girl suggested that "not all people have water because they are black". A considerable improvement 
in their conceptions on this theme was recorded during post-test, reflected on a difference of +7.4 on average of adequate responses. Thus, after the program all the children acknowledged that "everybody needs water", and commented that "water is important for people, for dogs, cats and for plants". Moreover, they were able to explain how people in different regions obtain access to water, as is apparent in the following excerpt: "there are people who don't have lakes or rivers nearby and they dig a hole on the ground that is called a 'drill' and they go one by one and take water".

\section{Uses of water and possibility of water shortage (Questions 8-12)}

A considerable improvement in children's understanding of domestic and other uses of water in everyday life, and -especially- of the possibility, reasons, and consequences of water shortage was recorded as a result of the 'Saving water' program. This is reflected on the increase of average adequate responses from 7 during pre-test, to 12.8 during post-test. Therefore, whilst in the pre-test the uses of the water that were mentioned were mainly focused on drinking, after the program the children mentioned a variety of uses, like cooking, bathing, washing the dishes and clothes, etc. During post-test the children also acknowledged that using too much water in daily activities may lead to water shortage.

\section{Ways of saving water (Questions 13-17)}

A significant development in children's conceptions during the program concerned the theme of suggesting ways of saving water, since their average adequate responses increased by 7.8 (from 5 during pre-test to 12.8 during post-test). Initially, the children understood the word 'saving' mainly in relation to money. After the completion of the program they recognized that we can also save water, stating that "we should not waste it" or that "we should save water". They were able to give reasons for adopting such a behaviour and ways of controlling the amount of water used in everyday activities, suggesting for example "not [to] leave the tap on when we brush our teeth", "using a watering can to water the plants", or "washing the car by using a bucket instead of a rubber tube". Also, during the post-test interviews comments like "I told my father to turn the tap off while shaving", or "I scolded my grandma because she uses the rubber tube to water her plants" revealed that apart from understanding, the children had become personally involved in the issue of saving water.

\section{Suggestions to inform the community about water shortage and conservation (Question 18)}

Another benefit of the program concerned the children's development of skills of informing the community about the possible water shortage and of advising ways of saving water. Initially (as the pre-test interviews revealed) they were unable to make relevant suggestions. In the course of different activities of the program they became familiar with a variety of informative texts and materials (photos, leaflets) and produced their own visual representations, namely the tables indicating uses of water during Activity 9, as well as the posters created during Activity 12 (see Appendix 2). Therefore, during the post-test the children readily proposed ways to inform the community, for example to "make posters and hang them everywhere in the city so people will learn about water shortage", "make flyers [explaining] the problem of water and throw them on the streets", or even "ring the bell and tell them not to use too much water because it might be used up". This outcome indicates that the program (especially activities $7,10,11$, and 12) and the material used and produced by the children assisted them in developing communication and argumentation skills for involving others in actions for sustainable water use.

\section{CONCLUSIONS}

In the present study an instructional program focused on water conservation for pre-school children was presented and evaluated. The program was structured in subsequent activities which employed everyday life experiences, aiming at enhancing the children's conceptual understanding of and their affective and active involvement in the issue of water conservation. Prior to the program implementation the children exhibited a partial and particularly limited understanding of the uses and the amount of water needed for our daily activities, or the possibility of its exhaustion, and therefore for the necessity of saving it. On the other hand, after they had participated in the program it became evident that their awareness of the issue had developed significantly.

Overall, the program evaluation confirmed that the children benefited both at the cognitive and the affective level. After the program, the vast majority of the children exhibited an adequate understanding of the basic concepts (water distribution and uses, the possibility of water shortage, 
ways of saving water) but also indicated an attitude of personal involvement and an adoption of values compatible with water conservation. Moreover, they developed a diversity of skills, important for understanding, communicating by formulating valid arguments, making informed decisions and taking responsible actions related to water shortage and water conservation.

Apparently, a determinant factor for the accomplishment of the program objectives was the interdisciplinary and holistic approach inherent in its design: the selection of a complex, multifaceted, yet real-life, familiar and everyday topic facilitated and at the same time required an integration of ideas, attitudes and skills from different fields, including language and literacy, biology, geography, mathematics, drama and art. The interdisciplinary character of the program probably assisted children in successfully using their newly acquired knowledge, values and skills, effectively transferring them from previous activities to subsequent ones and using them for constructing valid arguments. For example, when the pupils dramatized the story of the giant who wastes large amounts of water, they all wanted to become a member of the committee that would inform the giant how to save water in order to "let him know that there is not enough water in every region of the planet" or "water may be exhausted if we don't save it". Also, the posters created by the children (see Appendix 2) are indicative of their integrative use of their newly developed understanding and attitudes that lead to the participation in finding solutions and involving others to environmental problems.

When children deal with environmental problems from their early years, they demonstrate a higher level of knowledge about specific facts regarding the environment and shape environmentally responsible behaviors (Palmer \& Suggate, 1996). Education can and should contribute in shaping and maintaining such behaviors from an early age. Therefore, participation in appropriately designed Environmental Education programs can induce to young children a basic understanding and positive attitudes towards the issue of water conservation. The results of relevant previous studies (Papadopoulou \& Christidou, 2004; Middlestadt et al., 2001) support this argument.

Future studies could use a combination of different research tools and techniques for exploiting a variety of data sources (like children's verbal interactions in the classroom, or their drawings), in order to provide more in-depth and comprehensive insights on the process of children's knowledge and attitude development. Moreover, since the participants in this study far from constitute a representative sample, addressing a larger sample would provide more generalizable results. Furthermore, similar programs addressing other environmental issues could be developed, in order to produce a systematic mapping of the topics appropriate for dealing with in the nursery school.

\section{REFERENCES}

Bonnett, M. and Jacquetta, W. (1998), Environmental education and primary children's attitudes towards nature and the environment, Cambridge Journal of Education, 28, 159-173.

Bouguerra, M. (2000), L' eau sous la menace conjointe des pollutions et des marchés, Communication au séminaire "Perspectives de la Problématique Eau en Afrique à l'Orée du XXle siècle". Alexandrie, Octobre 2000. Retrieved from http://www.alliance21.org/fr/themes/water/docs/water_africa fr.rtf, January 16, 2007.

Brody, M. (1991), Understanding of pollution among 4th, 8th and $\overline{11}$ th grade students, Journal of Environmental Education, 22, 24 - 33.

Brody, M. (1994), Student science knowledge related to ecological crisis, International Journal of Science Education, 16, 421-435.

Brody, M., Chipman, E. and Marion, S. (1989), Student knowledge of scientific and natural resource concepts concerning acidic deposition, Journal of Environmental Education, 20, 32-42.

Bybee, R. W. (1993), Reforming science education: social perspectives and personal reflections, New York, Teachers College Press.

Chiras, D. (1985), Environmental Science: A Framework for Decision Making, California: The Benjamin/Cummings Publishing Company Inc.

Christidou, V. and Koulaidis, V. (1996), Students' models of the ozone layer and depletion. Research in Science Education, 26, 421-436.

Cohen, L. and Manion, L. (1994), Research Methods in Education, Fourth Edition, London, Routledge.

Dimitriou, A. and Christidou, V. (2007), Pupils' understanding of air pollution, Journal of Biological Education, 42, 24-29. 
European Communities. (2001), Water Resources, Abstraction and Use in European Countries, Statistics in Focus, theme 8-6/2001.

Fleer, M. and Robbins, J. (2003), "Hit and run research" with "hit and miss" results in early childhood science education, Research in Science Education, 33, 405-431.

Flogaiti, E. (1998), Environmental Education, Athens, Greek Letters [In Greek].

Global Water Partnership. (2000), Annual Report for the Financial Year 2000, Retrieved from: http://www.gwpforum.org/gwp/library/AR-2000USD\%20final.doc., June 17, 2001.

Koulaidis, V. and Christidou, V. (1999), Models of students thinking concerning the greenhouse effect and teaching implications, Science Education, 83, 559-576.

Marinopoulos, D. and Stavridou, E. (2002), The influence of a collaborative learning environment on primary students' conceptions about acid rain, Journal of Biological Education, 37, 18-25.

Matthews, M. R. (1994), Science Teaching: the Role of History and Philosophy of Science, London, Routledge.

Middlestadt, S., Grieser, M., Hernandez, O., Tubaishat, K., Sanchack, J., Southwell, B. and Schwartz, R. (2001), Turning minds on and faucets off: Water conservation Education in Jordanian schools, The Journal of Environmental Education, 32, 37-45.

Ministry of National Education and Religious Affairs. (2002), Interdisciplinary curriculum in preschool education, Athens.

Palmer, J. A. (1994), Acquisition of environmental subject knowledge in pre-school children: An international study, Children's Environments 11, 1-43. Retrieved from: www.colorado.edu/journals. PDF, February 12, 2004.

Palmer, J. and Suggate, J. (1996), Influences and experiences affecting the pro-environmental behaviour of educators, Environmental Education Research, 2, 109-121.

Papadopoulou, M. and Christidou, V. (2004), Multimodal comprehension and production by preschool children: An interdisciplinary approach of water conservation, International Journal of Learning, 11, 918-927.

Powney, J. and Watts, M. (1987), Interviewing in Educational Research, London, Routledge and Kegan Paul.

Sheehy, N. P., Wylie, J. W., McGuinness, C. and Orchard, G. (2000), How children solve environmental problems: using computer simulations to investigate systems thinking. Environmental Education Research, 6, 109-126.

Solomon, J. (1993), Teaching Science, Technology and Society, Cambridge, Open University Press.

Tytler, R. and Peterson, S. (2001), Deconstructing learning in science: Young children's responses to a classroom sequence on evaporation, Research in Science Education, 30, 339-355.

UNEP. (2000), Agenda 21: Protection of the quality and supply of freshwater resources: application of integrated approaches to the development, management and use of water resources, United Nations Environment Programme. Retrieved from: www.unep.org/Documents.multilingual,,February 20, 2007.

UNESCO. (1978), Intergovernmental Conference on Environmental Education, Tbilisi 1426/10/1977, Final Report, Paris.

UNESCO (1994), Water: An educational and informational approach. UNESCO International Science, Technology and Environmental Education Newsletter, 19, 1-3.

Volk, T. L., (1984), Project Synthesis and Environmental Education, Science Education, 68, 23-33. 


\section{Appendix 1 - Interview scheme}

1. Where does the water we use at home come from?

2. How does water come to our houses?

3. Where is there water on earth?

4. Can we drink any kind of water? Why?

5. Do all people in the world have plenty of water, like we do? [In the case of negative responses, the following questions were addressed]:

- Do [these] people live as we do?

- Do they use water as we do?

- What are the differences between our way of living and theirs?

6. Who needs water?

7. Is it possible to live without water?

8. How do we use water at home? At school?

9. Do we use large or small amounts of water in our daily life?

10. Could we run out of water?

11. How/why can we run out of water?

12. What would happen if we ran out of water?

13. Do you think we should do something in order for the water not to run out?

14. What can we do?

15. Can we use less water in some of our daily activities?

16. In which activities is it possible to use less water?

17. What do you do to save water?

18. What can we do to help other people learn about saving water?

Appendix 2 - Posters created by the groups of children (Activity 12)
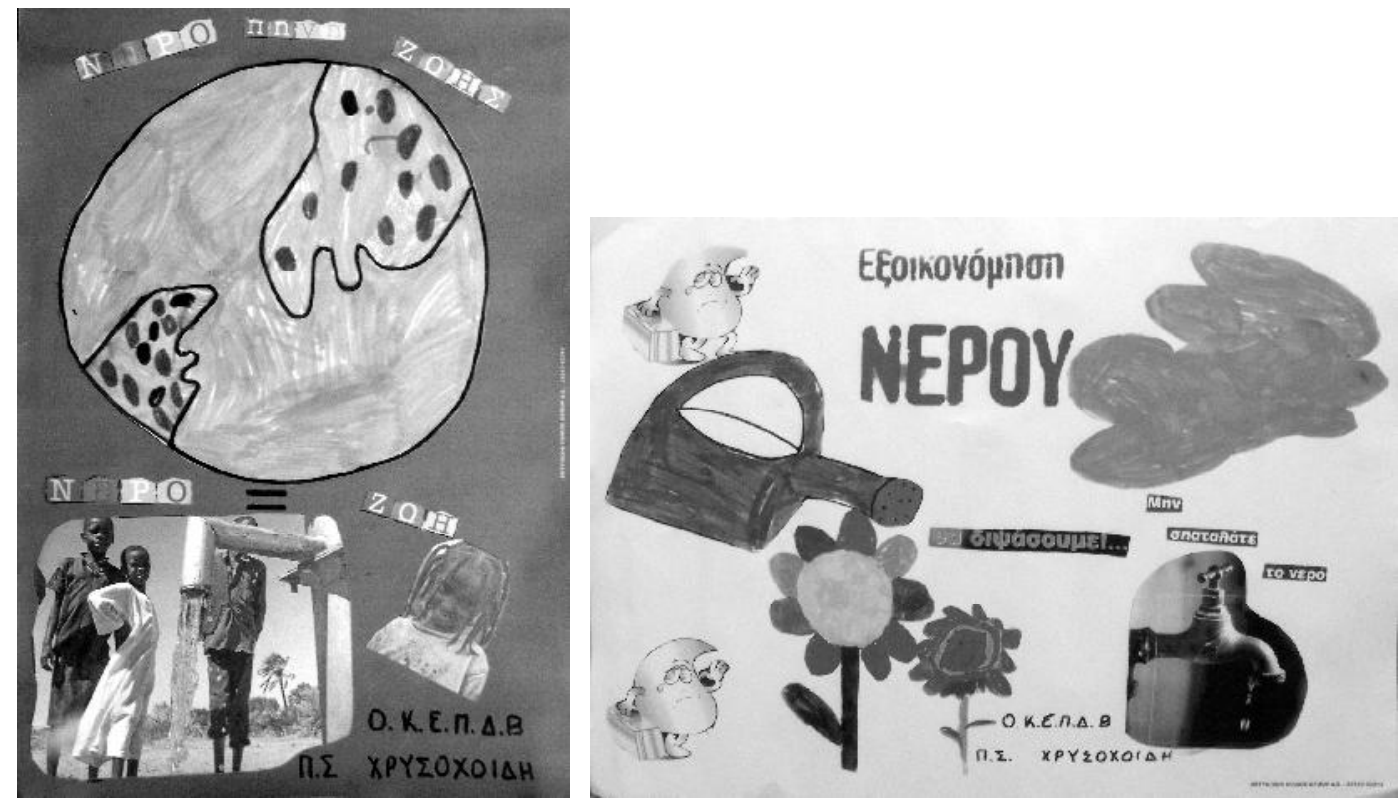